\title{
Sistem Pendukung Keputusan Pemilihan Supplier Produk Receiver Parabola dan Kipas Angin Pada Toko Irsan Jaya Rangkuti Menggunakan Metode Analytical Hierarchy Process (AHP)
}

\author{
Doni Winarso' ${ }^{1}$, Fuad Yasir $^{2}$ \\ ${ }^{1,2}$ Fakultas Ilmu Komputer, Universitas Muhammadiah Riau \\ 1email: doniwinarso@umri.ac.id
}

\begin{abstract}
Abstrak. Pemilihan supplier merupakan salah satu hal penting dalam menghadapi dunia bisnis retail yang semakin kompetitif. Hal ini dilakukan untuk mendapatkan produk yang berkualitas dengan harga yang bersaing. Pengambilan keputusan pemilihan supplier harus dilakukan secara tepat untuk menghindari terjadinya ketidakpuasan terhadap supplier dikarenakan rendahnya kualitas barang apabila hanya melihat kriteria harga terendah saja tanpa mempertimbangkan kriteria-kriteria lainnya. Permasalah pemilihan supplier ini dikategorikan sebagai Multi-Criteria Decision Making (MCDM). Metode MCDM yang digunakan untuk proses pemilihan supplier yaitu metode Analytical Hierarchy Process (AHP). Secara garis besar metode Analytic Hierarchy Process (AHP) merupakan proses membandingkan kriteria kedalam alternatif, semakin besar nilai yang dihasilkan, maka semakin besar pula prioritas untuk supplier tersebut terpilih. Hasil dari penelitian ini diharapkan dapat membantu Toko Irsan Jaya Rangkuti sebagai salah satu toko retail dalam memilih supplier sehingga didapatkanlah supplier terbaik.
\end{abstract}

Kata Kunci : Pemilihan Supplier, MCDM, Analytic Hierarchy Process (AHP).

\begin{abstract}
Supplier selection is one of the important things in facing the increasingly competitive retail business world. This is done to get quality products at competitive rates. Supplier selection decisions must be made appropriately to avoid dissatisfaction with suppliers due to the low quality of goods if they only look at the lowest price criteria without considering the other criteria. The supplier selection problem is categorized as a Multipel-Criteria Decision Making (MCDM). The MCDM method used for the best supplier selection process is the Analytic Hierarchy Process method (AHP). Outline the method of Analytic Hierarchy Process (AHP) is the process of comparing criteria into alternatives, the greater the value produced, then the greater the priority for the supplier chosen. The results of this study is expected to help the Irsan Jaya Rangkuti Store as one of the retail stores in choosing suppliers so that the best suppliers can be obtained.
\end{abstract}

Keywords: Supplier Selection, MCDM, Analytic Hierarchy Process (AHP).

\section{Pendahuluan}

Persaingan ekonomi bisnis di era globalisasi seperti sekarang ini semakin kompetitif. Hal ini didukung oleh perkembangan ilmu pengetahuan dan teknologi yang juga mengalami kemajuan. Oleh karena itu, perusahaan dituntut agar terus berinovasi dan dapat memberikan kepuasan terhadap konsumen dengan menjaga kualitas produk dan harga yang bersaing sehingga bisnis tetap dapat berjalan.

Saat ini, jenis perusahaan bisnis retail sedang populer di Indonesia yang menjual berbagai macam produk baik itu dalam bentuk eceran maupun dalam bentuk grosiran. Hal ini juga terjadi di Kabupaten Mandailing Natal khususnya di Kota Panyabungan. Bisnis usaha retail sangat banyak diminati terutama dalam penjualan peralatan rumah tangga, perabot, barang elektronik, dan lain sebagainya.

Toko Irsan Jaya Rangkuti merupakan salah satu toko retail yang masih tergolong baru dan beralamat di jalan Pusat Pasar Baru No 13, Panyabungan. Walaupun masih tergolong baru toko ini cukup diminati dilihat dari banyaknya konsumen datang berkunjung dan omset penjualan yang cukup baik. Toko Irsan Jaya Rangkuti menyediakan produk peralatan rumah tangga, perabot, dan barang elektronik. Berdasarkan hasil wawancara 
yang dilakukan penulis dengan pemilik toko, penjualan terbanyak terjadi pada barang elektronik dikarenakan harganya sedikit lebih murah dibandingkan toko lain dengan jenis barang yang sama.

Toko Irsan Jaya Rangkuti menjual berbagai jenis barang elektronik seperti televisi, setrika, kipas angin, receiver parabola, dan lain sebagainya. Saat ini, Penjualan barang elektronik yang paling diminati konsumen adalah receiver parabola dan kipas angin. Untuk mengantisipasi terjadinya permintaan dan pembelian barang dengan jumlah banyak oleh konsumen, toko ini harus memiliki jumlah persediaan atau stok barang yang banyak di gudang. Namun beberapa bulan belakangan ini terjadi permasalahan penurunan penjualan pada alat elektronik receiver parabola dan kipas angin dikarenakan banyaknya barang yang dikembalikan dari konsumen akibat produk dari barang tersebut rusak/cacat. Tentunya jika hal ini terus berlangsung akan mengakibatkan terjadinya penimbunan barang dan kerugian.

Berdasarkan permasalahan yang telah dipaparkan diatas, pemilik Toko Irsan Jaya Rangkuti harus mempertimbangkan kembali ketika melakukan pemilihan supplier dengan tepat sebagai prioritas suppliernya. Hal ini dilakukan agar Toko Irsan Jaya Rangkuti tetap mampu bersaing dengan para kompetitor dan menjaga kesetian dari konsumennya. Pemilihan supplier ini merujuk pada kriteria yang terdiri dari : produk, harga, kualitas, garansi dan kecepatan pengiriman produk. Untuk memudahkan proses pemilihan supplier dibuatkanlah metode Analytical Hierarchy Process (AHP). AHP cukup efektif dalam menyederhanakan dan mempercepat pengambilan keputusan dengan memecahkan persoalan tersebut ke dalam bagian-bagiannya (Magdalena, 2012).

\section{Tinjauan Pustaka}

\subsection{Sistem Pendukung Keputusan (SPK)}

Konsep Sistem Pendukung Keputusan atau Decision Support System pertama kali dikemukakan oleh Michael S. Scott Morton pada tahun 1971 dengan istilah Management Decision System. Michael S.Scott Morton mendefinisikan Sistem Pendukung keputusan sebagai sistem berbasis komputer interaktif, yang membantu para pengambil keputusan untuk memanfaatkan data dan berbagai model untuk memecahkan masalah-masalah tidak terstruktur (Turban, McLean, dan Wetherbe, 1999).

Menurut Little Man dan Watso Sistem Pendukung Keputusan adalah suatu sistem yang interaktif, yang membantu pengambil keputusan melalui penggunaan data dan model-model keputusan untuk memecahkan masalah-masalah yang sifatnya semi terstruktur dan tidak terstruktur (Suryadi, 2001).

Dari definisi yang dikemukakan diatas dapat disimpulkan bahwa Sistem Pendukung Keputusan adalah suatu sistem informasi interaktif yang ditujukan untuk membantu para pengambil keputusan dalam memecahkan masalah-masalah yang sifatnya semi terstruktur dan tidak terstruktur

\subsection{Multiple Criteria Decision Making (MCDM)}

Multiple Criteria Decision Making (MCDM) merupakan salah satu metode yang digunakan dalam pengambilan keputusan untuk menetapkan alternative terbaik dari sejumlah alternative berdasarkan beberapa kriteria tertentu (sri kusumadewi, sri hartati dkk, 2006). Tujuan dari MCDM adalah memilih alternatif terbaik dari beberapa alternatif atas dasar dari kriteria-kriteria yang telah ditentukan oleh pengambil keputusan.

\subsection{Metode Analytical Hierarchy Process (AHP)}

Metode Analytical Hierarchy Process (AHP) dikembangkan oleh Dr. Thomas L. Saaty dari Wharton School of Business pada tahun 1970 untuk mengorganisasikan informasi dan judgement dalam memilih alternatif yang paling disukai (Saaty, 1983).

Dengan menggunakan AHP, persoalan yang kompleks dapat disederhanakan dan dipercepat proses pengambilan keputusannya. Prinsip kerja AHP adalah menyederhanakan suatu persoalan kompleks yang tidak terstruktur menjadi bagian-bagiannya, serta menata dalam suatu hierarki kemudian tingkat kepentingan setiap kriteria yang telah ditentukan diberikan nilai numerik. 
Menurut Kusrini (2007), langkah-langkah dalam metode Analitical Hierarchy Process meliputi :

1. Mendefinisikan masalah dan menentukan solusi yang diinginkan, lalu menyusun hirarki dari permasalahan yang dihadapi. Penyusunan hirarki adalah dengan menentapkan tujuan yang merupakan sasaran sistem secara keseluruhan pada level teratas.

2. Menentukan prioritas elemen

a) Langkah pertama dalam menentukan prioritas elemen adalah membuat perbandingan pasangan, yaitu membandingkan elemen secara berpasangan sesuai kriteria yang diberikan.

b) Matriks perbandingan berpasangan diisi menggunakan bilangan untuk mempresentasikan kepentingan relatif dari suatu elemen terhadap elemen yang lainnya.

3. Sintesis, pertimbangan-pertimbangan terhadap perbandingan berpasangan disintesis untuk memperoleh keseluruhan prioritas. Hal-hal yang dilakukan dalam adalah :

a) Menjumlahkan nilai-nilai dari setiap kolom pada matrik.

b) Membagi setiap nilai dari kolom dengan total kolom yang bersangkutan untuk memperoleh normalisasi matriks.

c) Menjumlahkan nilai dari setiap baris dan membaginya dengan jumlah elemen untuk mendapatkan nilai rata-rata.

Tabel 1. Skala Penilaian Perbandingan Berpasangan.

\begin{tabular}{|c|c|c|}
\hline Intensitas Kepentingan & Keterangan & Penjelasan \\
\hline 1 & $\begin{array}{l}\text { Kedua elemen sama } \\
\text { pentingnya }\end{array}$ & $\begin{array}{l}\text { Dua elemen mempunyai } \\
\text { pengaruh yang sama } \\
\text { besar }\end{array}$ \\
\hline 3 & $\begin{array}{l}\text { Elemen yang satu } \\
\text { sedikit lebih penting } \\
\text { daripada elemen yang } \\
\text { lain }\end{array}$ & $\begin{array}{l}\text { Pengalaman dan } \\
\text { penilaian sedikit } \\
\text { menyokong satu } \\
\text { elemen dibandingkan } \\
\text { elemen lainnya }\end{array}$ \\
\hline 5 & $\begin{array}{l}\text { Elemen yang satu } \\
\text { lebih penting daripada } \\
\text { elemen yang lainnya }\end{array}$ & $\begin{array}{lr}\text { Pengalaman dan } \\
\text { penilaian sangat kuat } \\
\text { menyokong satu elemen } \\
\text { dibandingkan elemen } \\
\text { lainnya }\end{array}$ \\
\hline 7 & $\begin{array}{l}\text { Satu elemen jelas } \\
\text { lebih penting daripada } \\
\text { elemen lainnya }\end{array}$ & $\begin{array}{l}\text { Satu elemen yang kuat } \\
\text { disokong dan dominan } \\
\text { terlihat dalam praktek }\end{array}$ \\
\hline 9 & $\begin{array}{l}\text { Satu elemen mutlak } \\
\text { penting daripada } \\
\text { elemen lainnya }\end{array}$ & 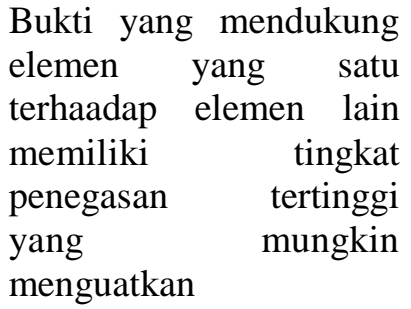 \\
\hline $2,4,6,8$ & $\begin{array}{l}\text { Nilai-nilai antara dua } \\
\text { nilai pertimbangan } \\
\text { yang berdekatan } \\
\text { (Compromise values) }\end{array}$ & $\begin{array}{l}\text { Nilai ini diberikan bila } \\
\text { ada dua kompromi } \\
\text { diantara dua pilihan }\end{array}$ \\
\hline
\end{tabular}

Sumber : Kusrini, (2007) 
4. Mengukur Konsistensi, dalam pembuatan keputusan, penting untuk mengetahui seberapa baik konsistensi yang ada karena kita tidak menginginkan keputusan berdasarkan pertimbangan dengan konsistensi yang rendah. Hal-hal yang dilakukan dalam langkah ini adalah :

a) Kalikan setiap nilai pada kolom pertama dengan prioritas relatif elemen pertama, nilai pada kolom kedua dengan prioritas relatif elemen kedua, dan seterusnya.

b) Menjumlahkan setiap baris.

c) Hasil dari penjumlahan baris dibagi dengan elemen prioritas relatif yang bersangkutan. Jumlahkan hasil bagi diatas dengan banyaknya elemen yang ada, hasilnya disebut $\lambda$ maks.

5. Hitung Indeks Konsistensi / Consistency Index (CI) dengan rumus :

$$
C I=\frac{(\lambda \text { maks }-\mathrm{n})}{n-1}
$$

Keterangan :

$\lambda \max \quad$ : Eigen value maksimum.

n : Banyaknya elemen.

6. Hitung Rasio Konsistensi / Consistency Ratio (CR) dengan rumus :

$$
\boldsymbol{C R}=\frac{\mathbf{C I}}{\mathbf{I R}}
$$

Keterangan :

CR : Consistency Ratio.

CI : Consistency Index.

IR : Indeks Random Consistency.

Tabel 2. Nilai Indeks Random (RI)

\begin{tabular}{cccccccccccccccc}
\hline $\mathbf{N}$ & $\mathbf{1}$ & $\mathbf{2}$ & $\mathbf{3}$ & $\mathbf{4}$ & $\mathbf{5}$ & $\mathbf{6}$ & $\mathbf{7}$ & $\mathbf{8}$ & $\mathbf{9}$ & $\mathbf{1 0}$ & $\mathbf{1 1}$ & $\mathbf{1 2}$ & $\mathbf{1 3}$ & $\mathbf{1 4}$ & $\mathbf{1 5}$ \\
\hline $\mathbf{R I}$ & 0 & 0 & 0.58 & 0.9 & 1.12 & 1.24 & 1.32 & 1.41 & 1.45 & 1.49 & 1.51 & 1.48 & 1.56 & 1.57 & 1.59 \\
\hline
\end{tabular}

- Memeriksa konsistensi hirarki. Jika nilainya lebih dari $10 \%$, maka penilai data harus diperbaiki. Namun jika rasio konsistensi (CI/IR) kurang atau sama dengan 0.1 maka hasil perhitungan bisa dinyatakan benar. Ilustrasi umum penggambaran metode Analytical Hierarchy Process (AHP) yang terdiri dari tujuan akhir, kriteria-kriteria dan alternatif pilihan dapat dilihat pada Gambar 1. dibawah ini :

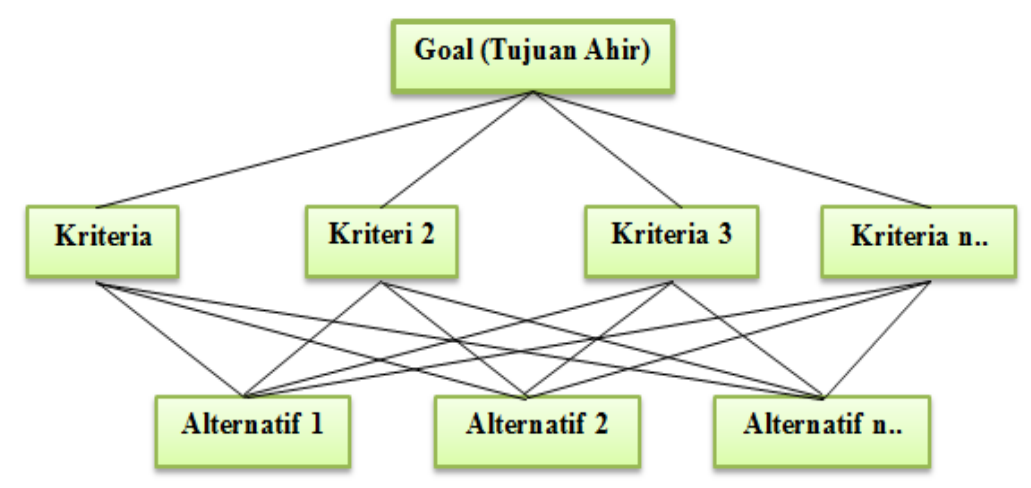


Gambar 1. Hirarki Metode Analytical Hierarchy Process (AHP)

\subsection{Penentuan Kriteria Supplier}

Berdasarkan hasil wawancara yang dilakukan, terdapat lima kriteria yang ditentukan dalam pemilihan supplier terbaik yaitu :

1. Kualitas, yaitu kesesuaian kualitas barang yang dikirim dengan spesifikasi yang telah disepakati bersama.

2. Garansi, yaitu jaminan perbaikan dan penggantian barang apabila terjadi kerusakan berdasarkan waktu yang telah ditentukan.

3. Harga, yaitu harga barang yang ditawarkan oleh pemasok/supplier.

4. Produk, yaitu hasil yang berwujud barang yang ditawarkan oleh pemasok/supplier.

5. Pengiriman barang, yaitu proses penyampaian barang dari pemasok ke konsumen.

\section{Metode Pengumpulan Data}

Pengumpulan data dilakukan dengan beberapa metode, yaitu :

\subsection{Wawancara}

Proses wawancara yaitu tanya jawab yang dilakukan penulis kepada pemilik, karyawan, dan pelanggan Toko Irsan Jaya Rangkuti tentang hal-hal yang berkaian dengan permasalahan penelitian.

\subsection{Studi Pustaka}

Studi pustaka yaitu penulis mempelajari dan membaca literatur-literatur yang berkaitan dengan penelitian sebagai penunjang untuk kelancaran penelitian.

\subsection{Observasi}

Oservasi yaitu proses yang dilakukan penulis untuk mengamati secara langsung objek penelitian pada Toko Irsan Jaya Rangkuti guna memperoleh informasi yang berkaian dengan permasalahan penelitian .

\section{Hasil dan Pembahasan}

\subsection{Mebuat Matriks Perbandingan dan Berpasangan.}

Pada tahapan ini dilakukan penilaian perbandingan antara satu kriteria dengan kriteria lainnya. Hasil penilaian antar kriteria dapat dilihat pada Tabel 3. di bawah ini :

Tabel 3. Matriks Perbandingan dan Berpasangan

\begin{tabular}{lccccc}
\hline \multicolumn{1}{c}{ Kriteria } & Produk & Harga & Kualitas & Garansi & Pengiriman \\
\hline Produk & 1 & $1 / 3$ & $1 / 9$ & $1 / 7$ & 2 \\
Harga & 3 & 1 & $1 / 3$ & $1 / 5$ & 3 \\
Kualitas & 9 & 3 & 1 & 3 & 7 \\
Garansi & 7 & 5 & $1 / 3$ & 1 & 5 \\
Pengiriman & $1 / / 2$ & $1 / 3$ & $1 / 7$ & $1 / 5$ & 1 \\
\hline
\end{tabular}

\subsection{Melakukan Normalisasi Pada Table Perbandingan Dan Berpasangan.}

Pada tahapan ini dilakukan normalisasi pada kriteria-kriteria yang telah diberikan nilai perbandingan. Hasil normalisasi pada table perbandingan dapat dilihat pada Tabel 4. dibawah ini :

Tabel 4. Normalisasi Perbandingan dan Berpasangan Antar Kriteria

\begin{tabular}{lccccccccccc}
\hline \multicolumn{1}{c}{ Kriteria } & Produk & Harga & Kualitas & Garansi & Pengiriman & \multicolumn{7}{c}{ Normalisasi } \\
\hline Produk & 1.00 & 0.33 & 0.11 & 0.14 & 2.00 & 0.049 & 0.03 & 0.06 & 0.03 & 0.11 & $\mathbf{0 . 2 8}$ \\
Harga & 3.00 & 1.00 & 0.33 & 0.20 & 3.00 & 0.15 & 0.10 & 0.17 & 0.04 & 0.17 & $\mathbf{0 . 6 3}$ \\
Kualitas & 9.00 & 3.00 & 1.00 & 3.00 & 7.00 & 0.44 & 0.31 & 0.52 & 0.66 & 0.39 & $\mathbf{2 . 3 2}$ \\
\hline
\end{tabular}




\begin{tabular}{lccccccccccc}
\hline Garansi & 7.00 & 5.00 & 0.33 & 1.00 & 5.00 & 0.34 & 0.52 & 0.17 & 0.22 & 0.28 & $\mathbf{1 . 5 3}$ \\
Pengiriman & 0.50 & 0.33 & 0.14 & 0.20 & 1.00 & 0.024 & 0.03 & 0.07 & 0.04 & 0.06 & $\mathbf{0 . 2 3}$ \\
Jumlah & $\mathbf{2 0 . 5 0}$ & $\mathbf{9 . 6 7}$ & $\mathbf{1 . 9 2}$ & $\mathbf{4 . 5 4}$ & $\mathbf{1 8 . 0 0}$ & $\mathbf{1}$ & $\mathbf{1}$ & $\mathbf{1}$ & $\mathbf{1}$ & $\mathbf{1}$ & $\mathbf{5 . 0 0}$ \\
\hline
\end{tabular}

Langkah berikutnya, menentukan bobot prioritas setiap kriteria ke-i, dengan membagi setiap nilai a dengan jumlah kriteria yang dibandingkan $(\mathrm{n})$, yaitu $: \boldsymbol{W} \boldsymbol{i}=\frac{\boldsymbol{a} \boldsymbol{i}}{\boldsymbol{n}}$. Sebagai contoh untuk menentukan Priority Vektor dari Kriteria Produk : $\boldsymbol{W} i=\frac{a i}{n} \quad \longrightarrow \boldsymbol{i}=\frac{\mathbf{0 . 2 8}}{\mathbf{5 . 0 0}}=\mathbf{0 . 0 6}$.

Hasil perhitungan pembobotan dari priority vector dapat dilihat pada Tabel.5 dibawah ini :

Tabel 5. Priority Vector Kriteria

\begin{tabular}{lc}
\hline \multicolumn{1}{c}{ Kriteria } & Priority Vector \\
\hline Produk & 0.06 \\
Harga & 0.13 \\
Kualitas & 0.46 \\
Garansi & 0.31 \\
Pengiriman & 0.05 \\
Jumlah & 1.00 \\
\hline
\end{tabular}

Setelah melakukan pembobotan pada priority vector, kemudian menghitung nilai dari lamda max (eigen value) dengan mengalikan secara matriks nilai dari normalisasi pada tabel perbandingan berpasangan dengan nilai pada priority vector. Persamaan rumus : $\left(\mathrm{A}_{1} * \mathrm{Y}_{1}+\mathrm{B}_{1} * \mathrm{Y}_{2}+\mathrm{C}_{1} * \mathrm{Y}_{3} \ldots \mathrm{n}\right)$. Hasil dari nilai lamda max semua kriteria dapat dilihat pada Tabel 6. dibawah ini :

Tabel 6. Lamda Max (Eigen Value) Semua Kriteria

\begin{tabular}{lc}
\hline \multicolumn{1}{c}{ Kriteria } & $\begin{array}{c}\text { Lamda Max (Eigen } \\
\text { Value) }\end{array}$ \\
\hline Produk & $\mathbf{0 . 0 5}$ \\
Harga & $\mathbf{0 . 1 2}$ \\
Kualitas & $\mathbf{0 . 5 3}$ \\
Garansi & $\mathbf{0 . 2 5}$ \\
Pengiriman & $\mathbf{0 . 0 6}$ \\
Rata-rata & $\mathbf{0 . 2 0}$ \\
\hline
\end{tabular}

\subsection{Menghitung Konsistensi Index (CI)}

Perhitungan konsistensi adalah menghitung penyimpangan dari konsistensi nilai, dari penyimpangan ini disebut Indeks Konsistensi. Rumus untuk menghitung persamaan Indeks Konsistensi (CI) adalah :

$$
\begin{aligned}
\boldsymbol{C I} & =\frac{(\lambda \max -\boldsymbol{n})}{\boldsymbol{n}-1} \\
& =\frac{(0.20-5)}{5-1}=-1.20
\end{aligned}
$$

Keterangan :

$\lambda_{\max } \quad$ : Eigen value maksimum.

$\mathrm{n} \quad$ : Banyaknya elemen. 


\subsection{Menghitung Konsistensi Rasio (CR)}

Memeriksa konsistensi rasio, jika rasio konsistensi kurang atau sama dengan 0.1 maka hasil perhitungan bisa dinyatakan benar atau $\mathrm{CR}<=0.1$. Rumus menghitung persamaan Konsistensi Rasio (CR) adalah :

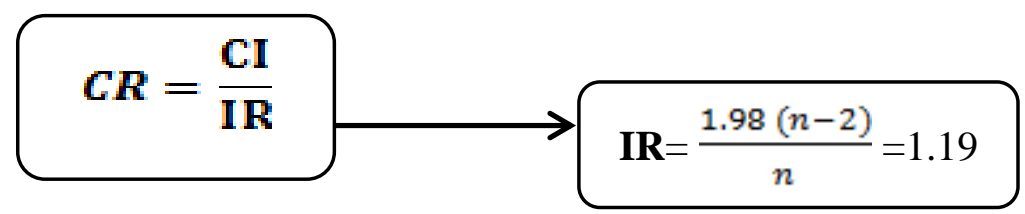

Sehingga :

$$
\begin{aligned}
C R & =\frac{\mathrm{CI}}{\mathrm{IR}} \\
& =\frac{-1.20}{1.19}=-1.01
\end{aligned}
$$

Keterangan :

CR : Consistency Ratio.

CI : Consistency Index.

IR : Indeks Random Consistency.

\section{Menghitung Nilai Antar Supplier}

5.1. Menghitung Nilai Perbandingan Antar Supplier Pada Kriteria Produk

Tabel 7. Perbandingan dan Berpasangan Antar Supplier Pada Kriteria Produk.

\begin{tabular}{lccccccc}
\hline \multicolumn{1}{c}{ Produk } & \multicolumn{2}{c}{ Supplier Padang } & Supplier Kotanopan & \multicolumn{2}{c}{ Supplier Sidempuan } \\
\hline Supplier Padang & \multicolumn{2}{c}{1} & 7 & & 3 & \\
Supplier Tebing & \multicolumn{2}{c}{$1 / 7$} & 1 & & 2 & \\
Supplier Sidempuan & \multicolumn{2}{c}{$1 / 3$} & $1 / 2$ & & 1 & \\
\hline \multicolumn{1}{c}{ Produk } & Supplier & Supplier & Supplier & \multicolumn{2}{c}{ Normalisasi } & \\
\hline Supplier Padang & 1.00 & 7.00 & 3.00 & 0.68 & 0.82 & 0.50 & $\mathbf{2 . 0 0}$ \\
Supplier Tebing & 0.14 & 1.00 & 2.00 & 0.10 & 0.12 & 0.33 & $\mathbf{0 . 5 5}$ \\
Supplier Sidempuan & 0.33 & 0.50 & 1.00 & 0.23 & 0.06 & 0.17 & $\mathbf{0 . 4 5}$ \\
Jumlah & $\mathbf{1 . 4 8}$ & $\mathbf{8 . 5 0}$ & $\mathbf{6 . 0 0}$ & $\mathbf{1}$ & $\mathbf{1}$ & $\mathbf{1}$ & $\mathbf{3 . 0 0}$ \\
\hline
\end{tabular}

Tabel 8. Normalisasi Antar Supplier Pada Kriteria Produk.

Tabel 9. Priority Vector, Lamda Max, CI, RI, dan CR Antar Supplier Pada Kriteria Produk.

\begin{tabular}{lrcccccc}
\hline \multicolumn{1}{c}{ Produk } & Priority Vector & Lamda Max & Avg & n & CI & RI & CR \\
\hline Supplier Padang & 0.67 & $\mathbf{0 . 6 8}$ & $\mathbf{0 . 3 3}$ & 3 & $\mathbf{- 1 . 3 3}$ & $\mathbf{0 . 6 6}$ & $\mathbf{- 2 . 0 2}$ \\
Supplier Tebing & 0.18 & $\mathbf{0 . 1 4}$ & & & & & \\
Supplier Sidempuan & 0.15 & $\mathbf{0 . 1 9}$ & & & & & \\
\hline
\end{tabular}




\section{Jumlah} 1

Berdasarkan tabel 9. diatas dapat diperoleh kesimpulan untuk kriteria produk Supplier Padang lebih unggul dibanding dengan supplier lainnya dengan nilai 0.68, diikuti Supplier Sidempuan dengan nilai 0.19 dan Supplier Tebing dengan nilai 0.14.

\subsection{Menghitung Nilai Perbandingan Antar Supplier Pada Kriteria Harga}

Tabel 10. Perbandingan dan Berpasangan Antar Supplier Pada Kriteria Harga.

\begin{tabular}{lccc}
\hline \multicolumn{1}{c}{ Harga } & Supplier Padang & Supplier Kotanopan & Supplier Sidempuan \\
\hline Supplier Padang & 1 & 5 & 3 \\
Supplier Tebing & $1 / 5$ & 1 & $1 / 5$ \\
Supplier Sidempuan & $1 / 3$ & 5 & 1 \\
\hline
\end{tabular}

Tabel 11. Normalisasi Antar Supplier Pada Kriteria Harga.

\begin{tabular}{lccccccc}
\hline \multicolumn{1}{c}{ Harga } & $\begin{array}{c}\text { Supplier } \\
\text { Padang }\end{array}$ & $\begin{array}{c}\text { Supplier } \\
\text { Kotanopan }\end{array}$ & $\begin{array}{c}\text { Supplier } \\
\text { Sidempuan }\end{array}$ & \multicolumn{3}{c}{ Normalisasi } & \\
\hline Supplier Padang & 1.00 & 5.00 & 3.00 & 0.65 & 0.45 & 0.71 & $\mathbf{1 . 8 2}$ \\
Supplier Tebing & 0.20 & 1.00 & 0.20 & 0.13 & 0.09 & 0.05 & $\mathbf{0 . 2 7}$ \\
Supplier Sidempuan & 0.33 & 5.00 & 1.00 & 0.22 & 0.45 & 0.24 & $\mathbf{0 . 9 1}$ \\
Jumlah & $\mathbf{1 . 5 3}$ & $\mathbf{1 1 . 0 0}$ & $\mathbf{4 . 2 0}$ & $\mathbf{1}$ & $\mathbf{1}$ & $\mathbf{1}$ & $\mathbf{3 . 0 0}$ \\
\hline
\end{tabular}

Tabel 12. Priority Vector, Lamda Max, CI, RI, dan CR

Antar Supplier Pada Kriteria Harga.

\begin{tabular}{lrcccccc}
\hline \multicolumn{1}{c}{ Harga } & Priority Vector & Lamda Max & Avg & n & CI & RI & CR \\
\hline Supplier Padang & 0.61 & $\mathbf{0 . 6 5}$ & $\mathbf{0 . 3 3}$ & 3 & $\mathbf{- 1 . 3 3}$ & $\mathbf{0 . 6 6}$ & $\mathbf{- 2 . 0 2}$ \\
Supplier Tebing & 0.09 & $\mathbf{0 . 1 0}$ & & & & & \\
Supplier Sidempuan & 0.03 & $\mathbf{0 . 1 9}$ & & & & & \\
Jumlah & 1 & & & & & & \\
\hline
\end{tabular}

Berdasarkan tabel 12. diatas dapat diperoleh kesimpulan untuk kriteria harga Supplier Padang lebih unggul dibanding dengan supplier lainnya dengan nilai 0.65, diikuti Supplier Sidempuan dengan nilai 0.19 dan Supplier Tebing dengan nilai 0.10.

\subsection{Menghitung Nilai Perbandingan Antar Supplier Pada Kriteria Kualitas}

Tabel 13. Perbandingan dan Berpasangan Antar Supplier Pada Kriteria Kualitas.

\begin{tabular}{lccc}
\hline \multicolumn{1}{c}{ Kualitas } & Supplier Padang & Supplier Kotanopan & Supplier Sidempuan \\
\hline Supplier Padang & 1 & $1 / 3$ & $1 / 7$ \\
Supplier Tebing & 3 & 1 & $1 / 5$ \\
Supplier Sidempuan & 7 & 5 & 1 \\
\hline
\end{tabular}

Tabel 14. Normalisasi Antar Supplier Pada Kriteria Kualitas.

\begin{tabular}{cccccccr}
\hline \multicolumn{1}{c}{ Kualitas } & $\begin{array}{c}\text { Supplier } \\
\text { Padang }\end{array}$ & $\begin{array}{c}\text { Supplier } \\
\text { Kotanopan }\end{array}$ & $\begin{array}{c}\text { Supplier } \\
\text { Sidempuan }\end{array}$ & \multicolumn{4}{c}{ Normalisasi } \\
\hline Supplier Padang & 1.00 & 0.33 & 0.14 & 0.09 & 0.05 & 0.11 & $\mathbf{0 . 2 5}$ \\
Supplier Tebing & 3.00 & 1.00 & 0.20 & 0.27 & 0.16 & 0.15 & $\mathbf{0 . 5 8}$ \\
\hline
\end{tabular}




\begin{tabular}{lccccccc}
\hline Supplier Sidempuan & 7.00 & 5.00 & 1.00 & 0.64 & 0.79 & 0.74 & $\mathbf{2 . 1 7}$ \\
Jumlah & $\mathbf{1 1 . 0 0}$ & $\mathbf{6 . 3 3}$ & $\mathbf{1 . 3 4}$ & $\mathbf{1}$ & $\mathbf{1}$ & $\mathbf{1}$ & $\mathbf{3 . 0 0}$ \\
\hline
\end{tabular}

Tabel 15. Priority Vector, Lamda Max, CI, RI, dan CR Antar Supplier Pada Kriteria Kualitas.

\begin{tabular}{lrcccccc}
\hline \multicolumn{1}{c}{ Kualitas } & Priority Vector & Lamda Max & Avg & n & CI & RI & CR \\
\hline Supplier Padang & 0.08 & $\mathbf{0 . 0 9}$ & $\mathbf{0 . 3 3}$ & 3 & $\mathbf{- 1 . 3 3}$ & $\mathbf{0 . 6 6}$ & $\mathbf{- 2 . 0 2}$ \\
Supplier Tebing & 0.19 & $\mathbf{0 . 1 6}$ & & & & & \\
Supplier Sidempuan & 0.72 & $\mathbf{0 . 7 4}$ & & & & & \\
Jumlah & $\mathbf{1}$ & & & & & & \\
\hline
\end{tabular}

Berdasarkan tabel 15. diatas dapat diperoleh kesimpulan untuk kriteria kualitas Supplier Sidempuan lebih unggul dibanding dengan supplier lainnya dengan nilai 0.74, diikuti Supplier Tebing dengan nilai 0.16 dan Supplier Padang dengan nilai 0.09.

\subsection{Menghitung Nilai Perbandingan Antar Supplier Pada Kriteria Garansi}

Tabel 16. Perbandingan dan Berpasangan Antar Supplier Pada Kriteria Garansi

\begin{tabular}{lccc}
\hline \multicolumn{1}{c}{ Garansi } & Supplier Padang & Supplier Kotanopan & Supplier Sidempuan \\
\hline Supplier Padang & 1 & $1 / 3$ & 5 \\
Supplier Tebing & 3 & 1 & 3 \\
Supplier Sidempuan & $1 / 5$ & $1 / 3$ & 1 \\
\hline
\end{tabular}

Tabel 17. Normalisasi Antar Supplier Pada Kriteria Garansi.

\begin{tabular}{lccccccr}
\hline \multicolumn{1}{c}{ Garansi } & $\begin{array}{c}\text { Supplier } \\
\text { Padang }\end{array}$ & $\begin{array}{c}\text { Supplier } \\
\text { Kotanopan }\end{array}$ & $\begin{array}{c}\text { Supplier } \\
\text { Sidempuan }\end{array}$ & \multicolumn{4}{c}{ Normalisasi } \\
\hline Supplier Padang & 1.00 & 0.33 & 5.00 & 0.24 & 0.20 & 0.56 & $\mathbf{0 . 9 9}$ \\
Supplier Tebing & 3.00 & 1.00 & 3.00 & 0.71 & 0.60 & 0.33 & $\mathbf{1 . 6 5}$ \\
Supplier Sidempuan & 0.20 & 0.33 & 1.00 & 0.05 & 0.20 & 0.11 & $\mathbf{0 . 3 6}$ \\
Jumlah & $\mathbf{4 . 2 0}$ & $\mathbf{1 . 6 7}$ & $\mathbf{9 . 0 0}$ & $\mathbf{1}$ & $\mathbf{1}$ & $\mathbf{1}$ & $\mathbf{3 . 0 0}$ \\
\hline
\end{tabular}

Tabel 18. Priority Vector, Lamda Max, CI, RI, dan CR

Antar Supplier Pada Kriteria Garansi

\begin{tabular}{lrcccccc}
\hline \multicolumn{1}{c}{ Garansi } & $\begin{array}{c}\text { Priority } \\
\text { Vector }\end{array}$ & Lamda Max & Avg & n & CI & RI & CR \\
\hline Supplier Padang & 0.33 & $\mathbf{0 . 2 6}$ & $\mathbf{0 . 3 3}$ & 3 & $\mathbf{- 1 . 3 3}$ & $\mathbf{0 . 6 6}$ & $\mathbf{- 2 . 0 2}$ \\
Supplier Tebing & 0.55 & $\mathbf{0 . 6 1}$ & & & & & \\
Supplier Sidempuan & 0.12 & $\mathbf{0 . 1 4}$ & & & & & \\
Jumlah & $\mathbf{1}$ & & & & & & \\
\hline
\end{tabular}

Berdasarkan tabel 18. diatas dapat diperoleh kesimpulan untuk kriteria garansi Supplier Tebing lebih unggul dibanding dengan supplier lainnya dengan nilai 0.61, diikuti Supplier Padang dengan nilai 0.26 dan Supplier Sidempuan dengan nilai 0.14. 


\subsection{Menghitung Nilai Perbandingan Antar Supplier Pada Kriteria Pengiriman}

Tabel 19. Perbandingan dan Berpasangan Antar Supplier Pada Kriteria Pengiriman

\begin{tabular}{lccc}
\hline Pengiriman & $\begin{array}{c}\text { Supplier } \\
\text { Padang }\end{array}$ & $\begin{array}{c}\text { Supplier } \\
\text { Kotanopan }\end{array}$ & Supplier Sidempuan \\
\hline Supplier Padang & 1 & $1 / 3$ & $1 / 5$ \\
Supplier Tebing & 3 & 1 & $1 / 3$ \\
Supplier Sidempuan & 5 & 3 & 1 \\
\hline
\end{tabular}

Tabel 20. Normalisasi Antar Supplier Pada Kriteria Pengiriman

\begin{tabular}{lccccccc}
\hline \multicolumn{1}{c}{ Pengiriman } & $\begin{array}{c}\text { Supplier } \\
\text { Padang }\end{array}$ & $\begin{array}{c}\text { Supplier } \\
\text { Kotanopan }\end{array}$ & $\begin{array}{c}\text { Supplier } \\
\text { Sidempuan }\end{array}$ & \multicolumn{4}{c}{ Normalisasi } \\
\hline Supplier Padang & 1.00 & 0.33 & 0.20 & 0.11 & 0.1 & 0.13 & $\mathbf{0 . 3 4}$ \\
Supplier Tebing & 3.00 & 1.00 & 0.33 & 0.33 & 0.30 & 0.22 & $\mathbf{0 . 8 5}$ \\
Supplier Sidempuan & 5.00 & 2.00 & 1.00 & 0.56 & 0.60 & 0.65 & $\mathbf{1 . 8 1}$ \\
Jumlah & $\mathbf{9 . 0 0}$ & $\mathbf{3 . 3 3}$ & $\mathbf{1 . 5 3}$ & $\mathbf{1}$ & $\mathbf{1}$ & $\mathbf{1}$ & $\mathbf{3 . 0 0}$ \\
\hline
\end{tabular}

Tabel 21. Priority Vector, Lamda Max, CI, RI, dan CR

Antar Supplier Pada Kriteria Pengiriman

\begin{tabular}{lrcccccc}
\hline \multicolumn{1}{c}{ Pengiriman } & Priority Vector & Lamda Max & Avg & n & CI & RI & CR \\
\hline Supplier Padang & 0.08 & $\mathbf{0 . 1 2}$ & $\mathbf{0 . 3 3}$ & 3 & $\mathbf{- 1 . 3 3}$ & $\mathbf{0 . 6 6}$ & $\mathbf{- 2 . 0 2}$ \\
Supplier Tebing & 0.19 & $\mathbf{0 . 2 5}$ & & & & & \\
Supplier Sidempuan & 0.72 & $\mathbf{0 . 6 3}$ & & & & & \\
Jumlah & $\mathbf{1}$ & & & & & & \\
\hline
\end{tabular}

Berdasarkan tabel 21. diatas dapat diperoleh kesimpulan untuk kriteria pengiriman Supplier Sidempuan lebih unggul dibanding dengan supplier lainnya dengan nilai 0.63, diikuti Supplier Tebing dengan nilai 0.25 dan Supplier Padang dengan nilai 0.12.

Tabel 22. Hasil Pembobotan Nilai dari Semua Kriteria

\begin{tabular}{lc}
\hline \multicolumn{1}{c}{ Nama Kriteria } & Nilai \\
\hline Produk & $\mathbf{0 . 0 5}$ \\
Harga & $\mathbf{0 . 1 2}$ \\
Kualitas & $\mathbf{0 . 5 3}$ \\
Garansi & $\mathbf{0 . 2 5}$ \\
Pengiriman & $\mathbf{0 . 0 6}$ \\
\hline
\end{tabular}

Berdasarkan tabel 22. diatas merupakan hasil dari perhitungan keseluruhan untuk pembobotan nilai dari semua kriteria. Nilai kriteria kualitas berada pada posisi pertama dengan nilai akhir 0.53 , kriteria garansi berada pada posisi kedua dengan nilai akhir 0.25 , keriteria harga berada pada posisi ketiga dengan nilai akhir 0.12 , kriteria pengiriman berada pada posisi keempat dengan nilai akhir 0.06 dan kriteria produk berada pada posisi kelima dengan nilai akhir 0.05 . 
Tabel 23. Hasil Pembobotan Nilai Antar Supplier Pada Semua Kriteria

\begin{tabular}{lccccc}
\hline \multicolumn{1}{c}{ Hasil } & Produk & Harga & Kualitas & Garansi & Pengiriman \\
\hline Supplier Padang & $\mathbf{0 . 6 8}$ & $\mathbf{0 . 6 5}$ & 0.09 & 0.26 & 0.12 \\
Supplier Tebing & 0.14 & 0.10 & 0.16 & $\mathbf{0 . 6 1}$ & 0.25 \\
Supplier Sidempuan & 0.19 & 0.24 & $\mathbf{0 . 7 4}$ & 0.14 & $\mathbf{0 . 6 3}$ \\
\hline
\end{tabular}

Tabel 24. Hasil Ahir Pemilihan Prioritas Supplier

\begin{tabular}{lr}
\hline \multicolumn{2}{c}{ Hasil Ahir Pemilihan Suplier } \\
\hline Supplier Padang & 0.23 \\
Supplier Tebing & 0.27 \\
Supplier Sidempuan & $\mathbf{0 . 5 0}$ \\
\hline
\end{tabular}

Berdasarkan Tabel 24. Hasil akhir pemilihan Prioritas Supplier tersebut, maka diperoleh informasi bahwa Supplier Sidempuan memperoleh nilai akhir paling besar yang menempati posisi pertama dengan nilai 0.50. Kemudian Supplier Tebing menempati posisi kedua dengan nilai akhir 0.27 Sedangkan Supplier Padang menempati posisi ketiga dengan nilai akhir 0.23. Secara umum hasil pemilihan supplier dapat dilihat pada Gambar 2. dibawah ini :

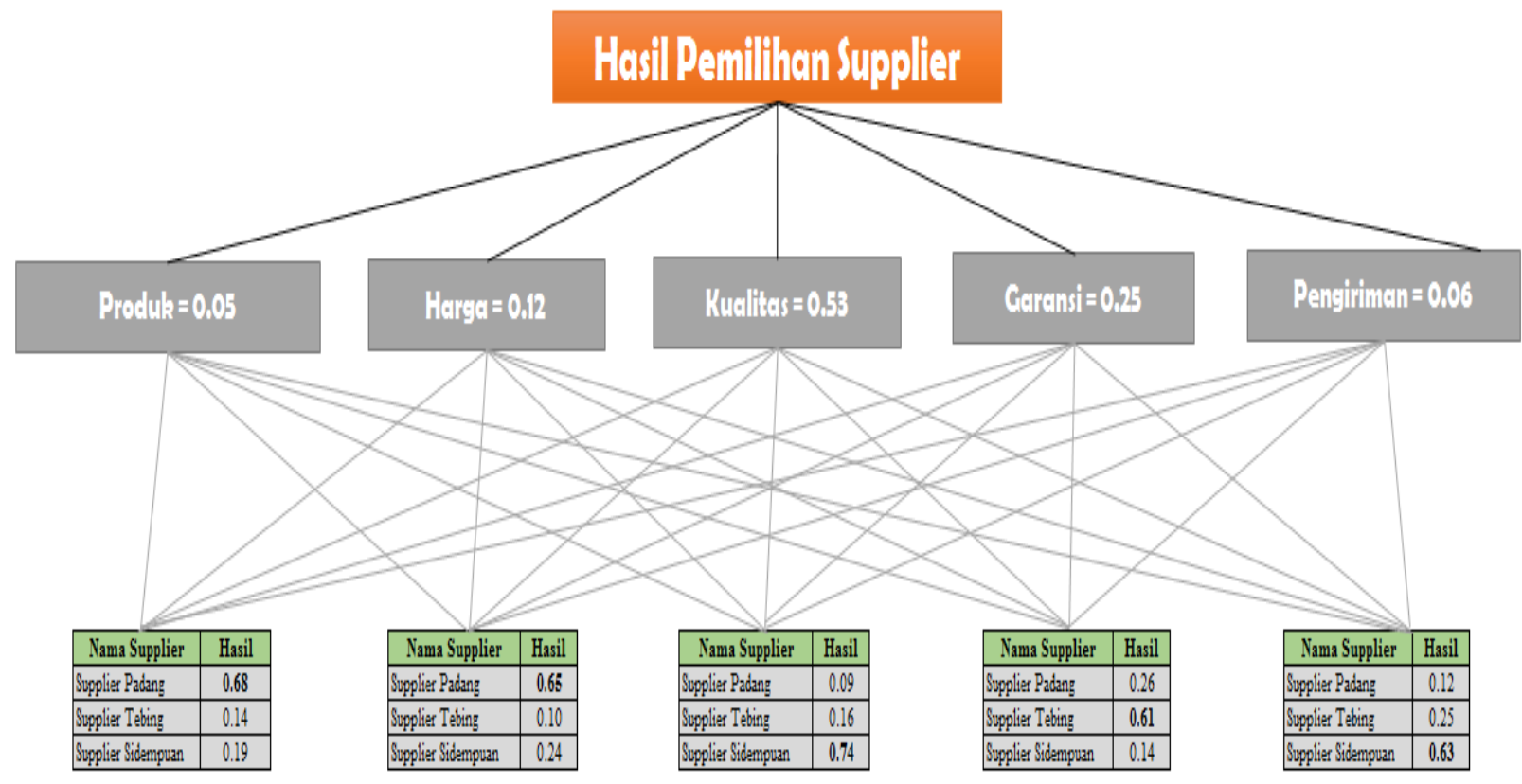

Gambar 2. Hasil Pemilihan Supplier. 


\section{Kesimpulan dan Saran \\ 6.1 Kesimpulan}

Sistem pendukung keputusan menggunakan metode Analytical Hierarchy Process (AHP) merupakan salah satu metode yang dapat digunakan untuk menentukan pemilihan supplier terbaik dengan melibatkan kriteria-kriteria yang telah ditentukan untuk memudahkan dalam proses pengambilan keputusan. Kriteria pemilihan supplier terdiri dari : produk, harga, kualitas, garansi dan pengiriman.

Nilai kriteria kualitas berada pada posisi pertama, kriteria garansi berada pada posisi kedua, keriteria harga berada pada posisi ketiga, kriteria pengiriman berada pada posisi keempat dan kriteria produk berada pada posisi kelima. Hasil ahir pembobotan nilai pada pemilihan supplier bahwa Suplier Sidempuan menempati posisi pertama, kemudian Supplier Tebing menempati posisi kedua dan Supplier Padang menempati posisi ketiga.

\subsection{Saran}

Sistem pendukung keputusan pemilihan supplier hendaknya dilakukan pengembangan lebih lanjut dengan menggunakan metode sistem pendukung keputusan lainnya untuk melihat kelebihan dari masing-masing metode.

\section{Referensi}

Anis, Yunus., Hersatoto Listiyono (2015). ANALYTIC HIERARCHY PROCESS SEBAGAI ALAT UNTUK PENGAMBILAN KEPUTUSAN (SPK) SELEKSI PEMASOK OBAT-OBATAN, 7(2).

Fahrozi, W. (2016). Penerapan Metode Analytical Hierarchy Process (AHP) dalam Menentukan Ras Ayam Serama. Creative Information Technology Journal, 3(3), 214-277. Retrieved from http://citec.amikom.ac.id/main/index.php/citec/article/view/78

Kusrini.(2007). Konsep dan Aplikasi Sistem Pendukung Keputusan. Yogyakarta : Andi

Kusumadewi, Sri., Hartati, S., A., \& Wardoyo, R. (2006). Fuzzy Multi-Attribut Decision Making (FUZZY MADM). Yogyakarta : Graha Ilmu

Magdalena, H. 2012. Sistem Pendukung Keputusan Untuk Menentukan Mahasiswa Lulusan Terbaik di Perguruan Tinggi (studi kasus stmik atma luhur pangkal pinang). Seminar nasional teknologi informasi dan komunikasi 2012 ISSN.2089-9815.

Noor, A. (2016). PENERAPAN METODE ANALYTICAL HIERARCHY PROCESS UNTUK PEMILIHAN TYPE SEPEDA MOTOR YAMAHA, 2, 7-14.

Prasetyo, B. (n.d.). SISTEM PENDUKUNG KEPUTUSAN PEMILIHAN PAKET INTERNET OPERATOR TELEKOMUNIKASI DENGAN METODE AHP ( ANALYTICAL HIERARCHY PROCESS ), 7-12.

Sepdiantara, Y. C., \& Haryanti, T. (2017). Sistem Pendukung Keputusan Pemilihan Supplier Peralatan Kantor Pada Direktorat Pembinaan Sekolah Dasar Menggunakan Metode Analytic Hierarchy Process (AHP).

Setyaningsih, I. (2011). ANALISIS PEMILIHAN SUPPLIER MENGGUNAKAN METODE ANALYTIC HIERARCHY PROCESS ( AHP ), 10(1), 7-13.

Suryadi, etc. 2001. Sistem Pendukung Keputusan. Remaja Rosdakarya : Bandung.

Turban, E., Aronson, E.J., \& Liang, T.P. (2005). Decision Support System and Intelligent System (Diterjemahkan oleh Prabantini, D.), edisi 7 jilid 1. Yogyakarta : Andi.

Turban, Efraim., Mclean, Ephraim., Wetherbe, James. 1999. Information Technology for Management Making Coinnections for Strategis Advantage. $2^{\text {nd }}$ Edition, JOhn Wile \&Sons, Inc. 